Bogusław Kotarba

DOI $10.14746 / \mathrm{ssp} .2016 .1 .10$

Uniwersytet Rzeszowski

\title{
Problemy współdziałania organów polskich gmin
}

Streszczenie: We współczesnych państwach istotną część zadań publicznych wykonują samorządy. Podobnie jak i w przypadku innych instytucji władzy, zadania swe wykonują za pośrednictwem organów. W artykule podjęto analizę relacji pomiędzy organami gminy - podstawowej jednostki samorządu terytorialnego. Przedstawiono, jak zmiany w prawie wpływały na pozycję i zakres kompetencji organu stanowiącego - rady gminy oraz wykonawczego - początkowo zarządu gminy, a następnie wójta (burmistrza, prezydenta). Przekładały się one również na ich wzajemne relacje. Przyjęto tezę, że współpraca organów gminy zależy nie tylko od rozwiązań instytucjonalno-prawnych, ale i od innych czynników, w tym układu sił, jaki się ukształtuje we władzach w wyniku wyborów. W oparciu o ten czynnik zaproponowano trzy modele wzajemnych relacji - idylliczny, optymalny oraz konfliktowy. Opisują one zalety i wady różnych stylów współdziałania organów gminy, które mogą się wytworzyć mimo jednakowych dla wszystkich ram prawnych.

Słowa kluczowe: samorząd terytorialny, organy gminy, rada gminy, wójt gminy, modele relacji organów gminy

\section{Wstęp}

Wpaństwach demokratycznych władza publiczna sprawowana jest za pośrednictwem organów, które są uprawnione do podejmowania władczych rozstrzygnięć. Zgodnie z monteskiuszowskim podziałem władzy mówimy o organach władzy ustawodawczej, wykonawczej i sądowniczej. Obok organów władzy centralnej, utożsamianej z parlamentem, rządem i prezydentem, funkcjonują również organy władz samorządowych - regionalnych i lokalnych. Sposób funkcjonowania władz i relacje pomiędzy ich organami wpływają istotnie na funkcjonowanie administracji publicznej na każdym poziomie, nie mniej z racji „bliskości” i zaspokajania podstawowych potrzeb mieszkańców, szczególną uwagę warto zwrócić na samorządy terytorialne. 
W artykule podjęto analizę uwarunkowań wpływających na funkcjonowanie organów gminy, a zwłaszcza na występujące między nimi relacje. Skoncentrowano się na ewolucji, jakiej podlegały i związanych z nią konsekwencjach. Przyjęto tezę, że obok zasadniczo wpływających na relacje pomiędzy organami gminy rozwiązań instytucjonalno-prawnych, ważne są również inne czynniki, w tym układ sił, jaki w nich panuje. Uwzględniając to uwarunkowanie, zaproponowano ujęcie relacji między organami gminy w trzy modele, które w aktualnym stanie prawnym odzwierciedlają ich zasadnicze style.

W pracy wykorzystano metodę analizy instytucjonalno-prawnej oraz metody porównawczą i historyczną. Zastosowano technikę analizy źródeł zastanych; wykorzystano literature przedmiotu, w tym opracowania autorstwa twórców reformy samorządowej. W skonstruowaniu modeli pomocne były dotychczasowe badania samorządów terytorialnych prowadzone przez autora, jak również jego praktyczne doświadczenia samorządowe.

\section{Organy gminy i ich ewolucja w latach 1990-2002}

Pierwszą regulacją prawną, która przesądziła o rodzaju organów odrodzonych samorządów gminnych oraz o trybie ich powoływania, była ustawa o zmianie Konstytucji Rzeczypospolitej Polskiej z 8 marca 1990 roku (Ustawa z dnia 8 marca 1990 r. o zmianie Konstytucji). Zgodnie z przyjętymi przepisami, gmina miała dysponować organem stanowiącym - radą, wybieraną przez mieszkańców, oraz powoływanym przez nią organem wykonawczym. Szczegółowe rozwiązania zostały przyjęte w ustawach: o samorządzie terytorialnym (Ustawa z dnia 8 marca $1990 \mathrm{r}$. o samorzqdzie) oraz ordynacja wyborcza do rad gmin (Ustawa z dnia 8 marca 1990 r. ordynacja).

Rada gminy była wybierana w wyborach powszechnych, liczyła od 15 radnych (w gminach do czterech tys. mieszkańców) do 45 radnych (w gminach od 100 do 200 tys. mieszkańców) oraz po pięciu radnych na każde dalsze rozpoczęte 100 tys. mieszkańców, jednak nie więcej niż 100 radnych.

Ze względu na reprezentowanie mieszkańców gminy oraz wykonywanie podstawowych kompetencji należących do samorządu terytorialnego rada gminy zajmowała (zajmuje?) eksponowaną pozycję w jego strukturze (Leoński, 1992, s. 56; Borodo, 2000, s. 42). Wśród kompe- 
tencji, które w sposób bezpośredni wpływały na relacje z organem wykonawczym należy wyróżnić powoływanie i ewentualne odwoływanie zarządu gminy oraz wypełnianie przez radę gminy funkcji kontrolnych, przy czym uwagę zwraca fakt, że początkowo nie istniał obowiązek powoływania komisji rewizyjnej. Ustawodawca stał na stanowisku, że rada gminy jest w stanie wypełniać funkcję kontrolną w ramach sesji (posiedzeń plenarnych) (Kumorek, 1996, s. 54). W praktyce okazało się to trudne do zrealizowania i w 1992 roku wprowadzono ustawowy obowiązek powoływania przez organ stanowiący komisji rewizyjnej (Ustawa z dnia 6 listopada 1992 r. o zmianie). Do 1995 roku (Ustawa z dnia 29 września 1995 r. o zmianie) ustawa o samorządzie terytorialnym nie mówiła nic na temat powoływania klubów radnych. Możliwość pewnego zinstytucjonalizowania różniących się między sobą grup radnych pozwala na bardziej „uporządkowane” funkcjonowanie tego organu. Od strony formalnej nic nie stało na przeszkodzie, by powoływanie klubów radnych przewidywał statut gminy (Leoński, 1994, s. 16-17). Jednak struktury samorządowe dopiero się tworzyły, większość radnych uczyła się funkcjonowania w nowych warunkach, co utrudniało przyjmowanie takich ,samodzielnych" rozwiązań organizacyjnych.

W 2001 roku znowelizowano ustawę o samorządzie gminnym (Ustawa z dnia 11 kwietnia 2001 r. o zmianie) i zmniejszono liczebność organów stanowiących. Rady gmin miały liczyć od 12 osób w gminach do 5 tys. mieszkańców do $30 \mathrm{w}$ gminach do 200 tys. mieszkańców oraz po pięciu radnych na każde dalsze rozpoczęte 100 tys. mieszkańców, jednak nie więcej niż 60 radnych. Nowelizacja nie miała praktycznego znaczenia, gdyż przepisy zmieniono ponownie zanim weszła w życie, w związku z ustawą o bezpośrednim wyborze wójta, burmistrza, prezydenta miasta.

Organem wykonawczym gminy był, jak już zaznaczono, liczący 4-7 osób zarząd gminy, na którego czele stał wójt ${ }^{1}$ (w miastach burmistrz albo prezydent miasta) jako jego przewodniczący. Zarząd wybierany był przez radę spośród jej członków, za wyjątkiem wójta i jego zastępców, którzy mogli pochodzić spoza rady. Ten wyjątek miał zabezpieczyć przed sytuacją, gdyby w składzie organu stanowiącego nie było osób o odpowiednich kwalifikacjach do pełnienia tych funkcji. Powoływanie członków zarządu przez radę gminy, dodatkowo spośród jej członków, miało na celu ścisłe powiązanie obu organów, ułatwiające ułożenie właściwych

${ }^{1}$ O ile w dalszej części tekstu nie zaznaczono inaczej, pojęcie „wójt” obejmuje również burmistrza i prezydenta miasta. 
relacji między nimi. W projekcie ustawy o samorządzie terytorialnym to wzajemne powiązanie miało jeszcze bardziej wzmacniać sprawowanie funkcji wójta przez przewodniczącego rady gminy. Ostatecznie ustawę przyjęto jednak z poprawką zakazującą łączenia tych funkcji. Wnioskodawca argumentował konieczność wprowadzenia zmiany pełnieniem przez radę funkcji nadzorczej nad wójtem. W przypadku łączenia obu stanowisk, wójt-przewodniczący rady byłby sędzią we własnej sprawie (Regulski, 2000, s. 305).

W ustawie o samorządzie terytorialnym w pierwotnym brzmieniu ustalono „ostre wymogi co do wyboru przewodniczącego zarządu” (Izdebski, 2001, s. 89). Wójt wybierany był „w oddzielnym, tajnym głosowaniu, bezwzględną większością głosów, w obecności co najmniej 2/3 ustawowego składu rady" (art. 28). Wójt nie miał jednak możliwości skompletowania „autorskiego" zarządu, w którym odgrywałby dominującą rolę, gdyż na jego wniosek wybierani byli tylko jego zastępcy. Pozostałych członków zarządu wybierała rada gminy spośród kandydatów zgłaszanych przez radnych (Piasecki, 2006, s. 66). Z uwagi na spory polityczne rady nie zawsze dokonywały wyboru zarządu w krótkim terminie (Leoński, 1998, s. 87). W związku z komplikacjami, które ujawniły się zwłaszcza na początku drugiej kadencji samorządów, związanymi z bojkotowaniem przez radnych opozycji procedury wyboru, wspomnianą już nowelizacją ustawy o samorządzie terytorialnym przyjętą we wrześniu 1995 roku, ustalono sześciomiesięczny okres na powołanie zarządu. W przypadku niedotrzymania tego terminu rada gminy ulegała rozwiązaniu z mocy prawa. Dodatkowo zrezygnowano z konieczności obecności 2/3 ustawowego składu rady podczas głosowania i określono, że warunkiem ważności wyboru jest uzyskanie przez kandydata bezwzględnej większości głosów w obecności przynajmniej połowy ustawowego składu rady. Wzmocniono również pozycję wójta, przyznając mu prawo zgłaszania kandydatów nie tylko na jego zastępców, ale i na pozostałych członków zarządu.

Zmiany ustawowe przyjęte w 1995 roku ustabilizowały na dłużej kształt i sposób powoływania organu wykonawczego gminy. Dopiero w 2001 roku między innymi ograniczono liczbę członków zarządu do pięciu (w gminach do 10 tys. mieszkańców do trzech), jak również skrócono czas na powołanie zarządu do trzech miesięcy od dnia ogłoszenia wyników wyborów (Ustawa z dnia 11 kwietnia 2001 r. o zmianie). Jednak regulacje te nie odegrały większej roli wobec zbliżającej się poważnej zmiany $\mathrm{w}$ ustroju gmin, związanej z wprowadzeniem bezpośredniego wyboru organu wykonawczego. 


\section{Relacje pomiędzy radą gminy a zarządem gminy}

Pierwsze lata funkcjonowania samorządów gminnych po ich odrodzeniu w 1990 roku charakteryzowała silna pozycja organów stanowiących. Takie wyraźne podporządkowanie organu wykonawczego gminy było wręcz uważane przez ekspertów za ,relikt koncepcji pełnowładztwa organu przedstawicielskiego" (Piasecki, 2006, s. 65). Wynikało nie tylko z ustawowego podziału kompetencji (Stanisław Leoński stwierdził, że „zarząd jest przede wszystkim organem wykonawczym rady” (Leoński, 1992, s. 61)), ale przede wszystkim z faktu powoływania przez radę zarządu gminy, wzmocnionego dodatkowo możliwością zgłaszania ,własnych" kandydatów na członków zarządu.

Dokonywanie w głosowaniu tajnym wyboru wójta jako przewodniczącego zarządu bezwzględną większością głosów w obecności co najmniej 2/3 ustawowego składu rady gminy, jak również pozostałych członków zarządu bezwzględną większością głosów ustawowego składu rady, miało dwojakie konsekwencje. $Z$ jednej strony sprawiało, że zarząd, a zwłaszcza wójt, dysponował wyraźnym poparciem większości rady gminy, co niewątpliwie ułatwiało realizację podejmowanych zamierzeń. Z drugiej, dawało pole do wspomnianych już targów politycznych i niejednokrotnie utrudniało powołanie zarządu. Stąd też nie dziwiła rezygnacja ustawodawcy z wymogu dokonywania wyboru wójta w obecności 2/3 ustawowego składu rady i obniżenie progu do połowy składu rady, czy też ustalenie sześciomiesięcznego okresu na sformowanie zarządu, $\mathrm{z}$ sankcją rozwiązania organu stanowiącego z mocy prawa w przypadku niedokonania wyboru w określonym terminie.

Ustawa o samorządzie terytorialnym w pierwotnym brzmieniu nie regulowała w specjalny sposób trybu odwołania wójta i zarządu gminy, co powodowało, że praktycznie w dowolnym momencie, bez konieczności podawania jakichkolwiek przyczyn organ wykonawczy (lub jego poszczególni członkowie) mógł być odwołany. Wystarczyło zachowanie takiego samego trybu, jak podczas wyboru zarządu.

Istniejący stan prawny powodował niestabilność zarządów gmin. Tylko w pierwszym półroczu 1991 roku z inicjatywy rad odwołano 21 wójtów, 10 burmistrzów, cztery zarządy oraz 123 członków zarządu (Piasecki, 2006, s. 89). Mimo że w 1992 roku zaostrzono warunki odwołania wójta i zarządu gminy (głosowanie w sprawie odwołania przeprowadzała rada gminy po zapoznaniu się z opinią komisji rewizyjnej, na następnej sesji po sesji, na której zgłoszono wniosek o odwołanie), do końca pierw- 
szej kadencji w 468 gminach zmieniono wójtów, w tym w 73 dwukrotnie, a w pięciu - trzykrotnie (Piasecki, 2006, s. 90). Dane te potwierdzają, że w dużej części samorządów gminnych organy stanowiące wykorzystywały swoją dominującą pozycję w strukturze lokalnej władzy. Nowelizacja ustawy o samorządzie terytorialnym z 29 września 1995 roku, po raz kolejny , istotnie utrudniła odwołanie przewodniczącego zarządu i całego zarządu przez radę (art. 28b-28e)" (Izdebski, 2009, s. 231). Wśród zmian znalazł się przepis mówiący, że odwołanie wójta bądź zarządu z przyczyny innej niż nieudzielenie absolutorium mogło nastąpić jedynie na pisemny, uzasadniony wniosek $1 / 4$ ustawowego składu rady. Natomiast poszczególnych członków zarządu rada mogła odwołać na uzasadniony wniosek wójta. Jeżeli wniosek o odwołanie zarządu lub wójta nie uzyskał wymaganej większości głosów, kolejny mógł być zgłoszony nie wcześniej niż po upływie sześciu miesięcy od poprzedniego głosowania. Przyjmowane od 1992 roku regulacje prawne w zakresie procedury odwołania zarządu gminy rozpoczęły proces stopniowego wzmacniania organu wykonawczego wraz z jego przewodniczącym. Jednak mimo tych działań pozycja organu stanowiącego była ciagle silniejsza z racji utrzymania kompetencji powoływania oraz odwoływania wójta i zarządu.

Zgodnie z ustawą o samorządzie terytorialnym organy stanowiące miały pełnić również funkcje kontrolne. Uprawnienia kontrolne rzutowały na relacje zachodzące pomiędzy radą a zarządem i gminy. Najważniejszym przejawem realizacji zadań kontrolnych przez organ stanowiący było postępowanie w sprawie absolutorium. „Akt absolutoryjny jest narzędziem kontroli przez organ stanowiący wykonania budżetu, odzwierciedlonego w sprawozdaniu rzetelnym i sporządzonym prawidłowo pod względem formalnym, jest wyrazem końcowej oceny działalności zarządu w tym względzie" (Sawicka, 1999, s. 8-9). Jednak początkowe rozwiązania prawne w tym zakresie były niejasne.

Generalnie absolutorium miało być poprzedzone przyjęciem (lub odrzuceniem) sprawozdania finansowego zarządu gminy za poprzedni rok, po wcześniejszym zaopiniowaniu przez komisję rewizyjną. Możliwość odrzucenia sprawozdania i nieudzielenia absolutorium zarządowi gminy mogłaby sugerować, że absolutorium było elementem istotnie wzmacniającym pozycję rady gminy wobec zarządu. Jednak w pierwotnym ustawodawstwie brak było przepisów, które przewidywałyby sankcje dla zarządu z tytułu nieotrzymania absolutorium (na przykład w postaci jego odwołania). Dopiero nowelizacja ustawy samorządowej z 1995 roku wprowadziła przepis, zgodnie z którym nieudzielenie absolutorium skutkowało automatycznie złoże- 
niem wniosku o odwołanie zarządu. Głosowanie nad odwołaniem zarządu mogło jednak odbyć się po 14 dniach, po wysłuchaniu opinii regionalnej izby obrachunkowej o nieudzieleniu absolutorium i po wyjaśnieniach zarządu. Tym samym droga od nieudzielenia absolutorium do odwołania zarządu była ciagle daleka, co wpisywało się w ogólny trend utrudniania możliwości odwołania zarządu i wzmacniania pozycji organu wykonawczego gminy. Niemniej, „w praktyce samorządowej absolutorium pozostało najbardziej krytycznym momentem w stosunkach na linii WÓJT-zarząd-rada" i umożliwiało doprowadzenie przez opozycję do próby sił, bez względu na faktyczny stan gospodarowania finansami gminy (Piasecki, 2006, s. 68).

$\mathrm{Na}$ współpracę pomiędzy zarządem a radą gminy wpływały również relacje przewodniczącego rady z wójtem. Rezygnacja w ustawie ustrojowej $\mathrm{z}$ powierzenia przewodniczącemu rady jednoczesnego pełnienia funkcji wójta - przewodniczącego zarządu, spowodowała w wielu gminach rywalizację o prymat pierwszeństwa w strukturze lokalnej władzy. „Pojawiły się konflikty, kto jest ważniejszy - wójt, który rządzi, ale jest wybierany przez radę, czy też przewodniczący rady, który ma mandat radnego pochodzący z wyborów" (Regulski, 2005, s. 115; zob. Kulesza, 2008, s. 80). Rolę przewodniczącego rady zaczęto jednak stopniowo ograniczać; ostatecznie w 2001 roku (Ustawa z dnia 11 kwietnia 2001 r. o zmianie) sprowadzono ją do prowadzenia jedynie obrad i organizowania pracy rady. Przewodniczącego rady pozbawiono również prawa rozstrzygającego głosu, którym dotychczas dysponował w sytuacji równego wyniku głosowania (art. 13a). Tą samą nowelizacją zmniejszono liczbę członków zarządu, co spowodowało wzrost znaczenia wójta i jego zastępców, którzy wchodzili w skład zarządu obligatoryjnie, a jednocześnie ograniczało możliwości oddziaływania radnych na organ wykonawczy. Uzyskana formalnoprawna przewaga wójta nad zarządem i radą wraz z jej przewodniczącym stworzyła „dogodne warunki do przekształcenia stanowiska WÓJTA w samodzielny organ samorządu wzmocniony demokratycznym mandatem pochodzącym z bezpośredniego wyboru" (Piasecki, 2006, s. 71).

\section{Wójt (burmistrz, prezydent miasta) jako jednoosobowy organ wykonawczy gminy}

W 2002 roku, przyjmując ustawę o bezpośrednim wyborze wójta, burmistrza, prezydenta miasta (Ustawa z dnia 20 czerwca 2002 r. o bezpośrednim) dokonano rewolucyjnej zmiany ustrojowej w polskim samo- 
rządzie. Rolę kolegialnych organów wykonawczych gmin przejął wójt, pochodzący z bezpośrednich wyborów. Wprowadzając tę reformę nie rozstrzygnięto jednak wcześniej, jaki charakter ma mieć jego funkcja. Jak zauważył Jerzy Regulski (Regulski, 2000, s. 309), ,[...] aby odpowiedzieć na pytanie: jak należy wybierać burmistrza?, najpierw trzeba odpowiedzieć na inne: kim ten burmistrz na być? [...] Burmistrza czy wójta można postrzegać dwojako: jako polityka lub jako menedżera". W pierwszym przypadku zadaniem wójta powinna być polityka rozwoju lokalnego, określanie celów, priorytetów i wyznaczanie zadań do realizacji aparatowi wykonawczemu. W drugim - zarządzanie gminą i wykonywanie funkcji władzy publicznej. Wójt powinien być więc autorytetem lokalnym lub sprawnym menedżerem. Mimo zastrzeżeń ekspertów wprowadzenie zmiany ustrojowej polegało głównie na zamianie w ustawie o samorządzie gminnym słowa „zarząd” na „wójt” (Regulski, 2005, s. 116).

W nowym porządku prawnym pozycja organu wykonawczego - wójta zdecydowanie się umocniła. Przede wszystkim objęcie funkcji wójta nie jest uzależnione od rady gminy. Niemożliwe jest również bezpośrednie odwołanie wójta przez radę, chociaż dysponuje ona inicjatywą podjęcia działań zmierzających do odwołania wójta w referendum. Procedura jest jednak ściśle określona i raczej wzmacnia dodatkowo organ wykonawczy (Ustawa z dnia 8 marca 1990 r. o samorzqdzie, art. 28a-28c). W przypadku nieudzielenia absolutorium wójtowi, co jest równoznaczne z podjęciem inicjatywy przeprowadzenia referendum w sprawie jego odwołania, głosowanie nad uchwałą o referendum odbywa się na kolejnej sesji po upływie 14 dni, po zapoznaniu się z opinią regionalnej izby obrachunkowej w sprawie uchwały o nieudzieleniu wójtowi absolutorium oraz wysłuchaniu wyjaśnień wójta. Uchwała zapada bezwzględną większością głosów ustawowego składu rady, w głosowaniu imiennym. Natomiast w przypadku podjęcia inicjatywy o referendum w sprawie odwołania wójta $\mathrm{z}$ innej przyczyny, pisemny wniosek zawierający uzasadnienie przyczyny odwołania musi poprzeć 1/4 ustawowego składu rady. Wniosek podlega zaopiniowaniu przez komisję rewizyjną. Również w tym przypadku głosowanie odbywa się na kolejnej sesji po upłynięciu 14 dni, a uchwała jest podejmowana w głosowaniu imiennym przy podniesionym progu wymaganej większości do 3/5 ustawowego składu rady. Dodatkowo, gdyby w ważnym referendum przeciwko wnioskowi rady opowiedziała się ponad połowa głosujących, rada gminy ulega rozwiązaniu z mocy prawa (Ustawa z dnia 15 września 2000 r. o referendum, art. 67). Przytoczone procedury wyraźnie utrudniają odwołanie wójta $\mathrm{z}$ inicjatywy rady. 
Wśród innych rozwiązań wzmacniających pozycję wójta w relacjach $\mathrm{z}$ organem stanowiącym (m.in. samodzielne powoływanie zastępców, jednoosobowe reprezentowanie gminy na zewnątrz, opracowywanie projektów uchwał rady gminy) szczególną uwagę zwracają kompetencje związane z budżetem. Opracowanie projektu budżetu należy do wyłącznych kompetencji wójta, a rada gminy nie może bez jego zgody wprowadzić w nim zmian zwiększających wydatki i jednocześnie zwiększających deficyt budżetowy. Przepisy te wzmacniają władzę wójta, gdyż praktycznie każde działanie podejmowane przez samorząd musi mieć odzwierciedlenie w budżecie, a realny wpływ na jego kształt ma organ wykonawczy. Radni, niedysponujący często fachową wiedzą, posiadający ograniczony dostęp do informacji, w praktyce najczęściej nie są w stanie wprowadzić zmian w projekcie budżetu bez ich uzgodnienia z wójtem. To z kolei powoduje, że dla realizacji partykularnych interesów grup, które reprezentują wolą mu się „nie narażać” w innych sprawach. Zwłaszcza w mniejszych gminach sprzyja to klientelistycznym postawom radnych.

Siłę wójta wzmacnia również to, że samodzielnie nie tylko opracowuje projekty uchwał rady gminy, lecz także określa sposób i czas ich wykonywania. $\mathrm{Z}$ tego powodu decyzje organu stanowiącego muszą być stosunkowo ogólne; w skrajnych przypadkach efekt realizacji uchwały przez wójta może znacząco odbiegać od pierwotnych zamiarów rady. Na straży samodzielności organu wykonawczego w wykonywaniu uchwał zdecydowanie stoją organy nadzoru nad samorządem oraz sądy. Na przykład Wojewódzki Sąd Administracyjny we Wrocławiu stwierdził: „Do zadań wójta należy zdecydowanie przez kogo, w jakich terminach i za pomocą jakich środków, w jakim trybie mają być zrealizowane zadania wynikające z uchwały. Sprawa wykonywania uchwał w ten sposób rozumiana należy wyłącznie do wójta" (Wyrok Wojewódzkiego Sądu).

W ręku wójta znajdują się również instrumenty, za pomocą których może skutecznie ograniczać lub utrudniać działania radnych i rady gminy, zwłaszcza w sytuacji konfliktu. Przede wszystkim w obecnym stanie prawnym biuro obsługi rady i jego pracownicy podlegają wójtowi, a rada (i jej przewodniczący) nie ma wpływu na ich pracę. Ponadto rada nie dysponuje samodzielnie środkami finansowymi, na przykład na niezależne ekspertyzy i opracowania. Na problemy te zwrócono uwagę w uzasadnieniu do prezydenckiego projektu „ustawy o samorządzie” (Uzasadnienie, s. 26-27).

Aktualny układ sił w relacjach wójt gminy - rada gminy trafnie opisują słowa J. Regulskiego (Regulski, 2005, s. 116): „Wzmacniając władzę 
wykonawczą w gminie, uczyniono z wójtów i burmistrzów osoby wyposażone w pełnię władzy, ale wyłączone spod jakiejkolwiek kontroli. [...] Może całkowicie ignorować radę [wójt - B. K.], której uchwały - nawet te odmawiające mu absolutorium - nie mają znaczenia. Wójt jest praktycznie nieodwoływalny [...]".

\section{Modele relacji rada gminy - wójt gminy}

Rozwiązania prawno-ustrojowe mają niewątpliwe bardzo duży wpływ na ułożenie wzajemnych stosunków i relacji organów gminy. W jakimś zakresie wręcz je determinują. Dotyczy to przede wszystkim konieczności przestrzegania wymogów formalnych, których naruszenie skutkowałoby możliwością uznania podjętych działań za nieważne. Jednak nie mniej istotną rolę odgrywają takie czynniki, jak układ sił we władzach lokalnych, kultura polityczna, niepisane zasady, lokalne prawo zwyczajowe czy osobowościowe cechy ludzi pełniących funkcje w samorządowych władzach. Zresztą wymienione czynniki mają wpływ nie tylko na relacje pomiędzy organami samorządów terytorialnych, ale i na styl sprawowania władzy w ogóle.

Wpływ czynników pozaprawnych na funkcjonowanie władz lokalnych powoduje, że w jednakowych warunkach normatywnych możliwe są różne style relacji pomiędzy organami gminy. Wśród wymienionych wcześniej pozaprawnych uwarunkowań istotną rolę odgrywa układ sił we władzach gminy, gdyż jest „stanem wyjściowym”, sprzyjającym lub utrudniającym ułożenie poprawnych relacji pomiędzy wójtem a radą gminy. W oparciu o kryterium układu sił można skonstruować charakterystyczne modele relacji między organami stanowiącymi i wykonawczymi. Pozwala to wyróżnić typy tych relacji, dokonać ich opisu i analizy. Należy zastrzec, że każdy model jest konstruktem idealnym, stąd praktyka samorządowej działalności w poszczególnych jednostkach niekoniecznie musi całkowicie odpowiadać jednemu z nich. Istotne jest, cechy którego modelu w relacjach przeważają.

Model idylliczny

Idylliczny model relacji pomiędzy organem stanowiącym a wykonawczym gminy (rys. 1) może ukształtować się w sytuacji, gdy: a) obydwa 
organy reprezentują tę samą partię (opcję) polityczną i zostały wyłonione z jednego komitetu wyborczego; b) obydwa organy zostały wyłonione $\mathrm{z}$ jednego komitetu wyborczego wyborców nieidentyfikujących się z jakąkolwiek partią polityczną; c) mimo pochodzenia poszczególnych radnych i wójta $\mathrm{z}$ różnych komitetów wyborczych (raczej wyborców niż partii politycznych), po wyborach następuje ich homogenizacja. Z pozoru pierwsze dwie sytuacje niewiele się różnią, jednak należy zwrócić uwagę, że w przypadku organów wyłonionych w ramach list stworzonych przez partie polityczne, w trakcie kadencji mogą one podlegać pewnym wpływom władz partyjnych, zwłaszcza w większych gminach, w których wybory odbywają się w systemie proporcjonalnym. Może się to również przekładać na relacje pomiędzy organami gminy. Problem ten raczej nie występuje w przypadku komitetów wyborców, gdyż po wyborach ulega on rozwiązaniu i brak jest podmiotu, który mógłby oddziaływać na wójta i radnych. Wyjątek mógłby dotyczyć komitetu wyborców stworzonego przez organizację pozarządową lub inne zinstytucjonalizowane gremium.

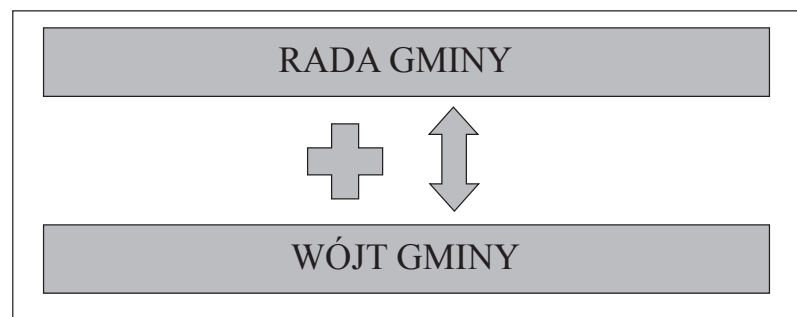

Rys. 1. Idylliczny model relacji rada gminy - wójt gminy

Źródło: Opracowanie własne.

Brak zróżnicowania pod względem przynależności do różnych grup politycznych (bądź innych) w ramach władz lokalnych powoduje, że relacje pomiędzy wójtem a radą gminy stają się specyficzne. Ta jednorodność zwykle nie powoduje wzajemnej równowagi pod względem siły wpływu na procesy decyzyjne. Wskazane wcześniej czynniki formalno-prawne wpływające na silną pozycję wójta we władzach gminy nie są nawet osłabiane działaniami podejmowanymi przez radę gminy lub jej część. Niczym niezakłócane relacje między organem stanowiącym a wykonawczym mogą rodzić dwojakie konsekwencje dla funkcjonowania samorządu gminnego. Ważniejsze z nich wskazano w tabeli 1. 


\section{Zalety i wady relacji rada gminy - wójt gminy w ramach modelu idyllicznego}

\begin{tabular}{|c|c|}
\hline Zalety & Wady \\
\hline $\begin{array}{l}\text { Możliwość realizacji pomysłów wójta jako } \\
\text { kreatora kierunków rozwoju gminy }\end{array}$ & $\begin{array}{l}\text { Brak krytycznej weryfikacji wizji i pomysłów } \\
\text { wójta }\end{array}$ \\
\hline $\begin{array}{l}\text { Duża swoboda i „samodzielność” wójta } \\
\text { w działaniu }\end{array}$ & $\begin{array}{l}\text { Groźba akceptacji (nawet po fakcie) nietrafio- } \\
\text { nych decyzji; }\end{array}$ \\
\hline $\begin{array}{l}\text { Ułatwienie wójtowi podejmowania decy- } \\
\text { zji w toku planowania, negocjacji z kon- } \\
\text { trahentami gminy }\end{array}$ & Stworzenie „kółka wzajemnej adoracji” \\
\hline $\begin{array}{l}\text { Targi polityczne i konflikty nie angażują } \\
\text { stron, które mogą koncentrować się na } \\
\text { działaniach na rzecz rozwiązywania pro- } \\
\text { blemów gminy }\end{array}$ & Klientelizm radnych \\
\hline Szybkość procesu decyzyjnego & $\begin{array}{l}\text { Wykraczanie wójta poza przysługujący mu } \\
\text { zakres kompetencji przy formalnym zacho- } \\
\text { waniu obowiązujących procedur }\end{array}$ \\
\hline $\begin{array}{l}\text { Bardzo silna, dodatkowo wzmocniona po- } \\
\text { zycja wójta }\end{array}$ & $\begin{array}{l}\text { Deprecjacja rady gminy jako organu stano- } \\
\text { wiącego, ,dyspozycyjność” radnych }\end{array}$ \\
\hline $\begin{array}{l}\text { Spokój i zgodna koegzystencja/współpra- } \\
\text { ca (?) }\end{array}$ & $\begin{array}{l}\text { Pasywność rady gminy, działalność sprowa- } \\
\text { dzona do zatwierdzania propozycji wójta }\end{array}$ \\
\hline
\end{tabular}

Źródło: Opracowanie własne.

Wśród zalet relacji w ramach modelu idyllicznego na plan pierwszy wysuwa się sprawność i przewidywalność procesu decyzyjnego. W zasadzie z góry wiadomo, że propozycje wójta zostaną zaakceptowane przez organ stanowiący. Jako przykład można wskazać gminę Kutno, w której w wyborach samorządowych w 2014 roku komitet wyborczy wyborców ubiegającego się o reelekcję burmistrza obsadził wszystkie mandaty w radzie miasta (Wybory samorządowe). Analiza protokołów sesji rady wykazała, że podczas pierwszych siedmiu posiedzeń organ stanowiący przyjął 47 uchwał, w tym 45 jednomyślnie, jedną przy jednym głosie przeciwnym (uchwała dotyczyła wysokości diet radnych) i jedną przy jednym głośnie wstrzymującym (Protokoły nr I-VII). Jednomyślność i sprawność procesu decyzyjnego nie zawsze przekłada się na korzystne dla gminy rozstrzygnięcia i trafność propozycji wójta. Brak ich krytycznej oceny i weryfikacji może spowodować podejmowanie błędnych decyzji. Stało się tak w gminie Ostrowice ${ }^{2}$, która została nadmiernie zadłużona,

${ }^{2}$ Gmina wiejska, licząca ok. 2,5 tys. mieszkańców, położona w województwie zachodniopomorskim. 
wskutek czego wojewoda wystapił do ministra administracji o jej likwidację (Gmina Ostrowice). Analiza głosowań nad 53 projektami uchwał podjętych przez radę gminy ${ }^{3} \mathrm{w} 2013$ roku oraz $30 \mathrm{w} 2014$ roku wykazała, że 79 uchwał $(95,2 \%)$ podjęto jednomyślnie, w tym uchwałę o udzieleniu wójtowi absolutorium (sic!), a tylko w przypadku czterech niektórzy radni wstrzymali się od głosu (Protokoły nr XVI-XX/13). Wprawdzie podczas dyskusji pojawiały się pojedyncze, krytyczne głosy radnych na temat sytuacji w gminie i przedkładanych projektów uchwał, jednak wydźwięk głosowań był jednoznaczny.

\section{Model optymalny}

Charakterystyczna dla modelu idyllicznego jedność budzi wątpliwości, co do jej autentyczności. Zdaniem niektórych badaczy (zob. Hallowell, 1993) jednomyślność opinii jest wręcz niemożliwa. Stąd też uprawnione jest przypuszczenie, że zgodne głosowanie w prawie każdej sprawie nie potwierdza całkowitej zgodności opinii i jest stanem nienaturalnym, choć w efekcie końcowym skutkuje podjęciem wiążących decyzji. Modelem relacji, w którym w naturalny sposób ujawniają się różne opinie, a ostateczne decyzje podejmowane są zgodnie ze zdaniem większości, jest model optymalny (rys. 2).

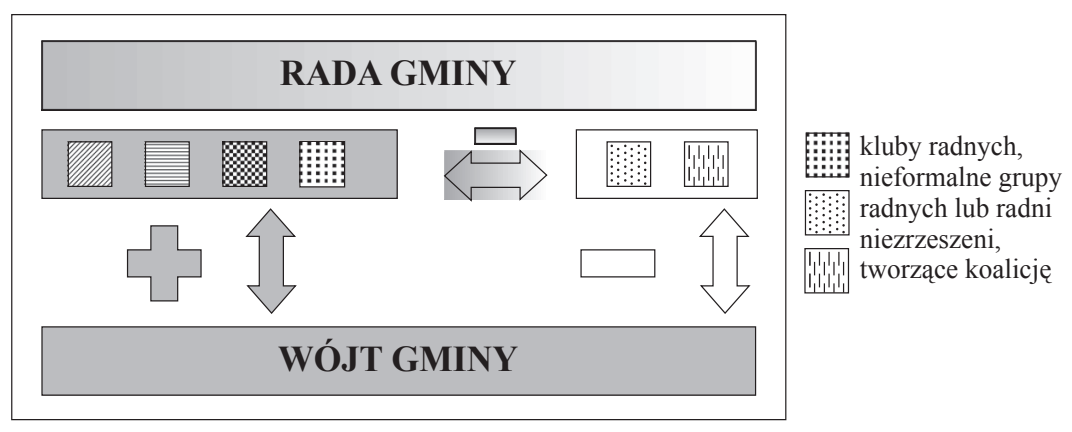

Rys. 2. Optymalny model relacji rada gminy - wójt gminy

Źródło: Opracowanie własne.

${ }^{3}$ Chociaż składała się z radnych pochodzących z czterech komitetów wyborczych (w tym dwóch „partyjnych”), na podstawie analizy protokołów sesji można stwierdzić, że uległa homogenizacji. 
Model optymalny kształtuje się w sytuacji, gdy w radzie gminy uformuje się popierająca wójta większość, zdolna do samodzielnego podejmowania rozstrzygnięć oraz opozycyjna wobec niej i wójta mniejszość. Można powiedzieć, że jest to standardowy układ sił we władzach lokalnych, wpływający korzystnie na relacje pomiędzy organami gminy. W zasadzie nie ma większego znaczenia czy większość pochodzi z jednej opcji politycznej/komitetu wyborczego, czy też powstaje wskutek zawiązania koalicji. „Przy regułach większościowych poszczególne części składowe ciała bądź zbiorowości podejmującej decyzje nie mają żadnego znaczenia, wzrastają natomiast szanse uzgodnienia wspólnego stanowiska, podjęcia decyzji" (Sartori, 1994, s. 274). Istotna jest stabilność i utrzymywanie przewagi liczbowej w organie stanowiącym. Nie mniej ważne są relacje większości z organem wykonawczym. W modelu optymalnym popiera ona wójta i stanowi jego zaplecze, umożliwiając realizację ,jego" polityki.

$\mathrm{Na}$ relacje pomiędzy organami wpływa również opozycja (wobec większości w radzie gminy oraz wobec wójta). Chociaż ma ograniczone możliwości decyzyjne, to jednak pełniąc rolę recenzenta poczynań wójta i wspierającej go większości może wpływać na ostateczne rozstrzygnięcia. Sprzyjać temu może kultura polityczna wójta oraz członków większości i przestrzeganie jednej z podstawowych zasad demokracji, jaką jest ograniczenie każdej władzy nie tylko pod względem czasowym, ale i przez prawa mniejszości (Zwierzchowski, 2000, s. 17). Zdarza się również, że opozycja jest w stanie doprowadzić do podjęcia decyzji w innym kształcie niż zakładała propozycja wójta, wbrew początkowej woli większości. Przykładem może być głośna na Podkarpaciu sytuacja, która miała miejsce we władzach Rzeszowa w roku 2008. Posiadający większość w radzie miasta i popierający prezydenta Klub Radnych Rozwój Rzeszowa zgłosił poprawkę do uchwały w sprawie nadania nazw ulicom i zaproponował nadanie jednej z nich imienia Władysława Kruczka, działacza komunistycznego. Oburzyło to opozycyjnych radnych Prawa i Sprawiedliwości, Platformy Obywatelskiej oraz radnych niezrzeszonych (Protokół nr XXIV/1/2008). Chociaż pierwotnie większość, przy akceptacji i wsparciu prezydenta, przeforsowała poprawkę, to jednak protesty opozycyjnych radnych wsparte kampanią medialna, doprowadziły do zmiany decyzji (Protokół nr XXVI/1/2008).

Podobnie jak w przypadku modelu idyllicznego, również w modelu optymalnym relacje rada gminy - wójt gminy mają zalety i wady, które w zróżnicowany sposób wpływają na funkcjonowanie gminy. O tym, któ- 
re z nich będą dominować przesądza kultura polityczna i cechy osobowościowe wójta oraz członków większości w radzie gminy.

Tabela 2

\section{Zalety i wady relacji rada gminy - wójt gminy w ramach modelu optymalnego}

\begin{tabular}{|c|c|}
\hline Zalety & Wady \\
\hline $\begin{array}{l}\text { Realizacja pomysłów wójta po ,przedysku- } \\
\text { towaniu problemu” }\end{array}$ & $\begin{array}{l}\text { Możliwość deprecjonowania propozycji } \\
\text { wójta przez opozycję }\end{array}$ \\
\hline $\begin{array}{l}\text { Swoboda i „samodzielność” wójta ograni- } \\
\text { czona działaniami opozycji w radzie }\end{array}$ & \multirow{2}{*}{$\begin{array}{l}\text { Groźba blokowania niektórych decyzji wójta } \\
\text { element niepewności co do reakcji radnych }\end{array}$} \\
\hline $\begin{array}{l}\text { Wiarygodność wójta w zakresie decyzji } \\
\text { w toku negocjacji, planowania }\end{array}$ & \\
\hline $\begin{array}{l}\text { Zdrowa rywalizacja na rzecz rozwiązywa- } \\
\text { nia problemów gminy }\end{array}$ & Uprzywilejowana pozycja większości \\
\hline „Przewidywalność” procesu decyzyjnego & Spowolnienie procesów decyzyjnych \\
\hline $\begin{array}{l}\text { Silna pozycja wójta, ograniczana krytyczną } \\
\text { oceną opozycji }\end{array}$ & $\begin{array}{l}\text { Ambicjonalne osłabianie pozycji wójta } \\
\text { przez opozycję }\end{array}$ \\
\hline Generalnie dobra współpraca & Możliwość nieliczenia się z opozycją \\
\hline Realny udział rady w zarządzaniu gminą & $\begin{array}{l}\text { Zbyt daleko idąca ingerencja rady gminy } \\
\text { w wykonywanie obowiązków przez wójta }\end{array}$ \\
\hline
\end{tabular}

Źródło: Opracowanie własne.

Wprawdzie trudno oczekiwać, że większość będzie ustępowała opozycji, ważne jest jednak, czy liczy się z jej zdaniem, poważnie analizuje zgłaszane uwagi oraz propozycje i przynajmniej w niektórych przypadkach je uwzględnia, czy też wójt wraz ze wspierającą go większością prowadzą „własną" politykę, ignorując opozycję. Tę drugą możliwość obrazują słowa jednego z opozycyjnych radnych miasta Rzeszowa: „Poczucie większości - takiej, jaką Państwo macie - budzi poczucie bezkrytycyzmu. Poczucie większości budzi poczucie wszechwiedzy. I pewnie Państwo przeforsujecie, według swojej własnej woli, to stanowisko Rady [dotyczące nadania ulicy imienia W. Kruczka - B. K.]” (Protokół nr XXIV/1/2008).

\section{Model konfliktowy}

Bezpośredni wybór wójta, niezależny od wyboru rady gminy, może sprawić, że organ wykonawczy nie będzie miał poparcia większości 
w organie stanowiącym. Sprzyja to pojawianiu się konfliktów, zarówno w łonie samej rady (co dla prowadzonej analizy jest mniej ważne, mimo istotnego wpływu na funkcjonowanie lokalnych władz), jak i pomiędzy większością radnych a wójtem, zwykle wspieranym przez opozycyjną mniejszość rady. Model relacji pomiędzy organami gminy, w którym wójta popiera „tylko” opozycja w radzie gminy, można określić mianem konfliktowego (rys. 3).

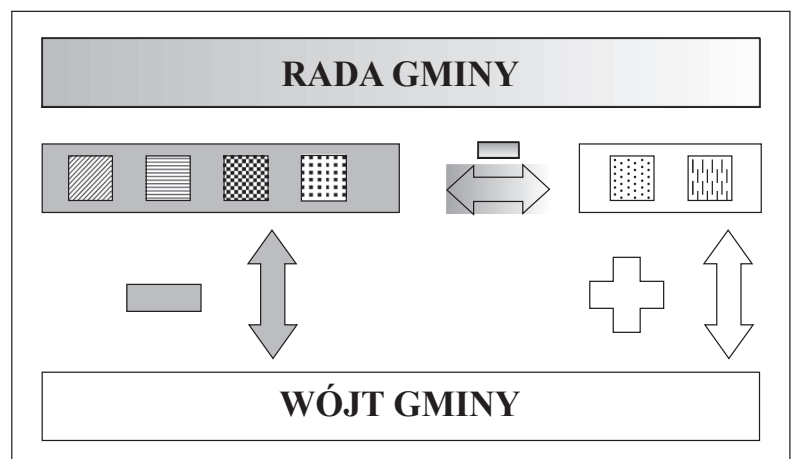

kluby radnych, nieformalne grupy radnych lub radni niezrzeszeni, tworzące koalicję

Rys. 3. Konfliktowy model relacji rada gminy - wójt gminy Źródło: Opracowanie własne.

O tym, że stworzenie takiego modelu jest uzasadnione (i konieczne) świadczy przykład samorządowych władz Rzeszowa IV kadencji (2002-2006). W stolicy regionu o wyraźnie prawicowych przekonaniach mieszkańców prezydentem wybrano członka Sojuszu Lewicy Demokratycznej, zaś w radzie miasta większość zdobyli przedstawiciele prawicy, którzy stanowili silną opozycję wobec prezydenta. Zaowocowało to szeregiem konfliktów (Kotarba, 2011, s. 9). Czy odbiły się one negatywnie zarówno na relacjach pomiędzy organami, jak i na funkcjonowaniu samorządu miejskiego i efektach jego działalności?

W powszechnej opinii konflikt jednoznacznie kojarzy się jako niepożądane, negatywne zjawisko społeczne. Jednakże skutki konfliktów nie są wyłącznie złe. Zwrócił na to uwagę m.in. Lewis A. Coser (Coser, 1956), tworząc funkcjonalną teorię konfliktu. Również Janusz Sztumski i Jacek Wódz (Sztumski, Wódz, 1984, s. 40) wyszczególnili dychotomiczne funkcje konfliktu. W tabeli 3 zaprezentowano zalety i wady relacji pomiędzy organami gminy w ramach modelu konfliktowego. 


\section{Zalety i wady relacji rada gminy - wójt gminy w ramach modelu konfliktowego}

\begin{tabular}{||l|l||}
\hline \multicolumn{1}{|c|}{ Zalety } & \multicolumn{1}{|c|}{ Wady } \\
\hline $\begin{array}{l}\text { Identyfikowanie się radnych i wójta z okre- } \\
\text { ślonym stanowiskiem/postawą w sytuacji } \\
\text { pojawienia się konfliktu }\end{array}$ & $\begin{array}{l}\text { Pojawianie się różnic pomiędzy radnymi, } \\
\text { wójtem, którzy mogą przyjmować odmienne } \\
\text { stanowisko wobec przedmiotu konfliktu }\end{array}$ \\
\hline $\begin{array}{l}\text { Integrowanie się radnych lub radnych } \\
\text { i wójta wokół zbliżonych stanowisk w spra- } \\
\text { wie konfliktu }\end{array}$ & $\begin{array}{l}\text { Integracja grup - stron konfliktów i utożsa- } \\
\text { miających się z nimi obserwatorów powo- } \\
\text { duje jednoczesną dezintegrację władz lokal- } \\
\text { nych (rady lub też rady i wójta) }\end{array}$ \\
\hline $\begin{array}{l}\text { Konflikty niejednokrotnie demaskują nie- } \\
\text { właściwą pracę władz gminy, złe decyzje, }\end{array}$ & $\begin{array}{l}\text { Istnieje możliwość, że wójt lub radni z pre- } \\
\text { zedytacją wywołają jakiś niewielki konflikt } \\
\text { dla ukrycia/zamaskowania innych, poważ- } \\
\text { niejszych problemów lub nieprawidłowości }\end{array}$ \\
\hline $\begin{array}{l}\text { Konflikty mogą nieść pozytywne zmiany } \\
\text { w sposobie funkcjonowania władz, jak i re- } \\
\text { alizacji zadań spoczywających na samorzą- } \\
\text { dzie gminnym }\end{array}$ & $\begin{array}{l}\text { Konflikty mimo możliwych również pozy- } \\
\text { tywnych skutków, wpływają negatywnie na } \\
\text { stosunki we władzach gminy oraz sprawność } \\
\text { podejmowania decyzji }\end{array}$ \\
\hline $\begin{array}{l}\text { Wywoływane konfliktami zmiany mogą } \\
\text { mięć progresywny charakter, prowadzący } \\
\text { do rozwoju określonych obszarów działal- } \\
\text { ności samorządu }\end{array}$ & $\begin{array}{l}\text { Konflikty mogą spowodować regres w roz- } \\
\text { woju jednostki samorządu gminnego }\end{array}$ \\
\hline \hline
\end{tabular}

Źródło: Opracowanie własne na podstawie: Sztumski, Wódz, 1984, s. 40.

Działalność samorządów terytorialnych podlega licznym regulacjom prawnym, które narzucają sposoby postępowania w określonych sytuacjach, również dotyczących procesów decyzyjnych. W zasadzie dosyć precyzyjne procedury powodują, że konflikty pojawiające się we władzach samorządowych są zinstytucjonalizowane, a decyzje konieczne dla normalnego funkcjonowania gminy i wypełniania przez samorząd spoczywających na nim obowiązków, są podejmowane. W relacjach między organami gminy, w sytuacji gdy wójt ma do czynienia z silną opozycją w organie stanowiącym, ważną rolę odgrywają jego cechy osobowościowe oraz umiejętności interpersonalne. Również w warunkach modelu konfliktowego możliwe jest skuteczne realizowanie propozycji wójta. W przywołanym już przypadku samorządu Rzeszowa IV kadencji, w którym konflikty pomiędzy organami gminy miały wręcz codzienny charakter, negatywnego oddziaływani konfliktów na realizację zadań miasta nie zauważył jego prezydent (Kotarba, 2011, s. 226). Potwierdza to nie tylko subiektywna opinia włodarza miasta, ale i obiektywna, oparta 
na skwantyfikowanych wskaźnikach ocena rozwoju miasta (Złota setka). To, że konflikty ogólnie nie zaszkodziły rozwojowi miasta, a w pewnych przypadkach odegrały pozytywną rolę, nie świadczy o tym, że nie ujawniły się ich negatywne skutki. Konflikty źle wpływały na współpracę we władzach samorządowych, jak również utrudniały podejmowanie decyzji (Kotarba, 2011, s. 226).

\section{Zakończenie}

Samorządy terytorialne odgrywają ważną rolę w polskim systemie politycznym. Wśród nich szczególne miejsce zajmują gminy - podstawowe jednostki, których utworzenie w 1990 roku rozpoczęło odradzanie samorządu w Polsce. Zgodnie z wolą ustawodawcy w strukturze władz gminnych funkcjonują organy stanowiące i wykonawcze. Sposób ich powoływania, a także kompetencje ewoluowały z upływem czasu. Początkowo obydwa miały kolegialny charakter, przy czym rada gminy - organ stanowiący, pochodziła z wyborów powszechnych, natomiast zarząd gminy - organ wykonawczy, wybierany był przez radę. Taka forma wyłaniania lokalnych władz wpłynęła na uzyskanie dominującej pozycji przez radę gminy. Współpraca między organami nie zawsze układała się poprawnie, a zarządy gmin nie pracowały w stabilnych warunkach $\mathrm{z}$ racji łatwości ich odwołania. Między innymi te mankamenty we wzajemnych relacjach spowodowały stopniowe wzmacnianie organów wykonawczych, poprzez wprowadzanie nowych regulacji prawnych. Ich zwieńczeniem było zastąpienie kolegialnego zarządu gminy organem jednoosobowym - wójtem, pochodzącym z bezpośredniego wyboru. Nastąpiło to w 2002 roku. Była to rewolucyjna zmiana, która przesądziła ostatecznie o dominującej pozycji organu wykonawczego w systemie gminnej władzy. Przyjęte rozwiązania instytucjonalno-prawne wpływają istotnie na współpracę organów i ich wzajemne relacje. Jednakże, jak wynika z przeprowadzonej analizy, zależą one również od innych czynników. Potwierdziła się przyjęta teza o istotnym znaczeniu układu sił, jaki zostanie wytworzony w lokalnych władzach w wyniku wyborów powszechnych. W tych samych ramach prawnych mamy do czynienia z różnymi stylami współpracy między radą gminy i wójtem. Relacje między organami gminy można odnieść do zaproponowanych modeli: idyllicznego, optymalnego i konfliktowego. Każdy z nich ma zalety i wady, które wpływają na funkcjonowanie lokalnych władz i realizację spoczywających na nich obowiązków. 


\section{Bibliografia}

Borodo A. (2000), Samorzad terytorialny. System prawno finansowy, Wydawnictwo Prawnicze PWN, Warszawa.

Coser L. A. (1956), The Functions of Social Confict, Free Press, London.

Gmina Ostrowice na Pomorzu Zachodnim jak Grecja. Zbankrutuje i zostanie wchłonięta (2015), „Dziennik.pl”, 7.07.2015, http://wiadomosci.dziennik.pl/wydarzenia/artykuly/494801, ostrowice-na-pomorzu-zachodnim-moga-zbankrutowac-wchlonie-je-drawsko-pomorskie.html, 20.07.2015.

Halowell J. H. (1993), Moralne podstawy demokracji, przeł. J. Marcinkowski, Polskie Wydawnictwo Naukowe, Warszawa.

Izdebski H. (2001), Samorzqd terytorialny. Podstawy ustroju i działalności, Wydawnictwo Prawnicze LexisNexis, Warszawa.

Izdebski H. (2009), Samorzq̨ terytorialny. Podstawy ustroju i działalności, LexisNexis, Warszawa.

Kotarba B. (2011), Walka polityczna na forum Rady Miasta Rzeszowa, Wydawnictwo Uniwersytetu Rzeszowskiego, Rzeszów.

Kulesza M. (2008), Budowanie samorzqdu. Wybór tekstów ze „,Wspólnoty” 1990-2007, Municipum SA, Warszawa.

Kumorek B. (1996), Komisja rewizyjna i kontrola wewnętrzna w gminie, Zachodnie Centrum Organizacji, Poznań-Zielona Góra.

Leoński Z. (1992), Ustrój samorzqdu terytorialnego w RP, Towarzystwo Naukowe Organizacji i Kierownictwa w Poznaniu, Poznań.

Leoński Z. (1994), Ustrój i zadania samorzadu terytorialnego w Polsce, Polski Dom Wydawniczy „Ławica”, Poznań.

Leoński Z. (1998), Samorzqd terytorialny w RP, Wydawnictwo C. H. Beck, Warszawa.

Leoński Z. (2001), Ustrój samorzqdu terytorialnego w RP, Towarzystwo Naukowe Organizacji i Kierownictwa w Poznaniu, Poznań.

Piasecki A. K. (2006), Menadżer i polityk. Wójt, burmistrz, prezydent miasta, Wydawnictwo „Profesja”, Kraków.

Protokoły nr I-VII sesji Rady Gminy Kutno, http://www.bip.gminakutno.pl/strony/2951.dhtml, 20.07.2015.

Protokoły nr XVI-XX/13 i XXI-XXV/14 sesji Rady Gminy Ostrowice, http://ug.ostrowice.ibip.pl/public/?id=159769, 20.07.2015.

Protokół nr XXIV/1/2008 sesji Rady Miasta Rzeszowa, http://bip.erzeszow.pl/ file/1823/prot_sesja_24_2008.pdf, 20.07.2015.

Protokół nr XXVI/1/2008 z XXVI sesji Rady Miasta Rzeszowa, http://bip.erzeszow. pl/file/1825/prot_sesja_26_2008.pdf, 20.07.2015.

Regulski J. (2000), Samorzqd III Rzeczypospolitej, Wydawnictwo Naukowe PWN, Warszawa.

Sartori G. (1994), Teoria demokracji, przeł. P. Amsterdamski i D. Grinberg, Wydawnictwo Naukowe PWN, Warszawa. 
Sawicka K. (1999), Absolutorium komunalne jako narzędzie wewnętrznej kontroli finansowej w jednostkach samorzqdu terytorialnego, „Finanse Komunalne”, nr 4.

Sztumski J., Wódz J. (1984), Z problematyki konfliktów społecznych i dezorganizacji społecznej, PAN Oddz. w Katowicach, Komisja Filozofii i Socjologii, Zakład Narodowy im. Ossolińskich, Wrocław.

Ustawa z dnia 11 kwietnia 2001 r. o zmianie ustaw: o samorzqdzie gminnym, o samorzadzie powiatowym, o samorzqdzie województwa, o administracji rzqdowej $w$ województwie oraz o zmianie niektórych innych ustaw, Dz. U. 2001, Nr 45, poz. 497.

Ustawa z dnia 15 września 2000 r. o referendum lokalnym, tekst. jedn. Dz. U. 2013, poz. $706 \mathrm{z}$ późn. zm.

Ustawa z dnia 20 czerwca 2002 r. o bezpośrednim wyborze wójta, burmistrza, prezydenta miasta, Dz. U. 2002, Nr 113, poz. 984.

Ustawa z dnia 29 września 1995 r. o zmianie ustawy o samorzqdzie terytorialny oraz niektórych innych ustaw, Dz. U. 1995, Nr 124, poz. 601.

Ustawa z dnia 6 listopada 1992 r. o zmianie ustawy o samorzqdzie terytorialnym, Dz. U. 1992, Nr 100, poz. 499.

Ustawa z dnia 8 marca 1990 r. o samorzqdzie terytorialnym, Dz. U. 1990, Nr 16, poz. 95. Ustawa z dnia 8 marca 1990 r. o zmianie Konstytucji Rzeczypospolitej Polskiej, Dz. U. 1990, $\mathrm{Nr} 16$, poz. 94.

Ustawa z dnia 8 marca 1990 r. ordynacja wyborcza do rad gmin, Dz. U. 1990, Nr 16, poz. 96.

Uzasadnienie do projektu ustawy o współdziałaniu $w$ samorzqdzie terytorialnym na rzecz rozwoju lokalnego i regionalnego oraz o zmianie niektórych ustaw (2012), http://www.prezydent.pl/download/gfx/prezydent/pl/defaultopisy/ 2373/4/1/uzasadnienie.rtf, 17.07.2015.

Wybory samorządowe 2014, Państwowa Komisja Wyborcza, Miasto Kutno, http://wybory2014.pkw.gov.pl/pl/wyniki/gminy/view/100201, 20.07.2015.

Wyrok Wojewódzkiego Sądu Administracyjnego we Wrocławiu z dnia 23 stycznia 2013 r., III SA/Wr 507/12, Lex nr 1274822.

Złota setka samorzadów (2004), „Rzeczpospolita” z dnia 6.07.2004.

Zwierzchowski E. (2000), Opozycja parlamentarna, w: Opozycja parlamentarna, red. E. Zwierzchowski, Wydawnictwo Sejmowe, Warszawa.

\section{Problem of cooperation between bodies of Polish municipalities}

\section{Summary}

In modern countries an important part of public duties is performed by local governments. As in the case of other institutions of power, they perform their tasks through the authorities. The article analyses the relationship between the municipal 
authorities - the basic unit of the local government. It shows how changes in the law affect the position and responsibilities of both the decision-making body - the municipal council, and the executive body - initially the board of the municipality, then the commune head (mayor, president). These changes also translate into mutual relations. A thesis has been assumed that the cooperation of the municipal authorities depends not only on institutional and legal solutions, but also on other factors, including the balance of power which is formed in the government after the elections. Based on this factor three models of relationships have been proposed - idyllic, optimal and confrontational. They describe the advantages and disadvantages of different styles of interactions which may appear among municipal authorities, despite identical legal frameworks for all of them.

Key words: local government, municipal authorities, the municipal council, commune head, models of relations among commune authorities 
